\title{
Pengembangan Modul Sintaksis Bermodel Discovery Learning untuk Mahasiswa Pendidikan Bahasa Indonesia
}

\author{
Faizatur Rohmah \\ Universitas Negeri Surabaya \\ faizaturrohmah2@gmail.com
}

\begin{abstract}
How to cite (in APA Style): Rohmah, F. (2020). Pengembangan Modul Sintaksis Bermodel Discovery learning untuk Mahasiswa Pendidikan Bahasa Indonesia. Jurnal Pendidikan Bahasa dan Sastra, 20(1), 111-120. DOI: https://doi.org/10.17509/bs_jpbsp.v20i1.25976
\end{abstract}

Article History: Received (13 January 2020.); Revised (13 March 2020); Accepted (1 April 2020) Journal homepage: http://ejournal.upi.edu./index.php/BS_JPBSP

\begin{abstract}
Abstrak: Penelitian ini bertujuan untuk (1) mendeskripsikan proses pengembangan modul sintaksis dengan model discovery learning, dan (2) mendeskripsikan kualitas modul sintaksis dengan model discovery learning pada materi sintaksis. Model pengembangan ini menggunakan model ADDIE (analysis, design, development, implementation, evaluate). Hasil penelitian ini adalah (1) proses pengembangan modul sintaksis yang dirancang melalui lima tahapan, yaitu analisis, perancangan, pengembangan, penerapan, dan evaluasi; (2) kualitas modul sintaksis yang diuji melalui kriteria kevalidan, kepraktisan, dan keefektifan. Hasil data kevalidan diperoleh dari penilaian validator ahli dengan kategori sangat valid. Data keefektifan dari aktivitas mahasiswa berkategori baik, aktivitas dosen berkategori sangat baik, dan ketuntasan belajar mahasiswa berkategori tuntas. Data kepraktisan yang diperoleh dari hasil penilaian terhadap keterlaksanaan RPS dengan kategori sangat baik, respons mahasiswa, dan respons dosen dengan kategori positif.
\end{abstract}

Kata Kunci: pengembangan; modul; sintaksis; discovery learning

\section{Development of Syntax Module with Discovery learning Models for the Students of Indonesian Language Department}

\begin{abstract}
This study aims to (1) describe the process of syntax module development with the discovery learning model, and (2) describe the quality of a syntax module with the discovery learning models on a syntax material. This development model uses the ADDIE model (analysis, design, development, implementation, evaluation). The results of this study are (1) the process of the syntax module development designed through five stages, namely analysis, design, development, application, and evaluation; (2) the quality of the syntax module tested through the criteria of validity, practicality, and effectiveness. The validity data results are obtained from the expert validator assessment is of category very valid. The effectiveness data of student activities is of category good, the activity of the lecturers is of category very good, and the completeness of student learning is complete. The practicality data obtained from the assessment of the implementation of RPS is of category very good, student responses, and lecturer responses are of category positive.
\end{abstract}

Keywords: development; module; syntax; discovery learning 


\section{PENDAHULUAN}

Pasal 45 Undang-Undang Nomor 14 Tahun 2005 tentang kewajiban dosen menyebutkan, "Dosen wajib memiliki kualifikasi akademik, kompetensi, sertifikat pendidik, sehat jasmani dan rohani, dan memenuhi kualifikasi yang dipersyaratkan satuan pendidikan tinggi tempat bertugas, serta memiliki kemampuan untuk mewujudkan tujuan pendidikan nasional". Berdasarkan kompetensi tersebut, dosen wajib memiliki kompetensi inti yaitu mampu membuat bahan ajar sesuai dengan Kurikulum Perguruan Tinggi (KPT), perkembangan mahasiswa, dan perkembangan teknologi informatika. Kemampuan dosen harus senantiasa ditingkatkan dalam berbagai bentuk kegiatan seperti: pelatihan, workshop, seminar, dan pengabdian masyarakat sesuai dengan bidang keilmuan. Peningkatan kemampuan diharapkan dapat membuat suatu pembelajaran di kelas menyenangkan sehingga mahasiswa termotivasi dalam mengikuti perkuliahan, tidak hanya mengisi daftar hadir dan nilai semata. Pembelajaran harus direncanakan dan diarahkan untuk membentuk mahasiswa yang cerdas, mandiri, inovatif dalam menghadapi perkembangan zaman.

Lokakarya Applied Approach (AA)
atau pendekatan terapan yang diselenggarakan di Universitas Islam Nahdlatul Ulama (Unisnu) Jepara (Jawa Pos, 2018) menghasilkan bahwa dosen diwajibkan membuat tugas dalam bidang pembelajaran yang meliputi materi taksonomi, strategi kognitif, dan menulis bahan ajar. Berdasarkan hal tersebut, tugas dosen adalah membuat bahan ajar yang diimplementasikan dalam proses pembelajaran di kelas. Prastowo (2013,p.297) menyatakan bahwa bahan ajar merupakan materi pembelajaran yang dibuat secara runtut untuk menciptakan suasana belajar yang efektif. Bahan ajar memiliki peran pokok dalam proses belajar mengajar yang berbentuk buku sebagai sumber utama atau buku sebagai penunjang, contohnya seperti modul, buku pelajaran, bandout, maket, bahan ajar interaktif, bahan ajar audio, dan sebagainya. Berdasarkan proses pembelajaran, bahan ajar yang didesain secara khusus untuk mahasiswa agar mampu belajar mandiri tanpa bergantung kehadiran dosen disebut modul. Modul adalah bahan ajar mandiri yang di dalamnya terdapat petunjuk mengajar untuk pendidik, tes, dan petunjuk untuk peserta didik. Modul dapat digunakan dalam proses belajar mengajar di kelas dan sistem belajar jarak jauh.

Setelah dilakukannya observasi melalui wawancara disertai pengisian angket oleh dosen dan mahasiswa Pendidikan Bahasa Indonesia Universitas Billfath bahwa mahasiswa secara umum mengalami kesulitan pada mata kuliah sintaksis. Hal tersebut dikarenakan dalam proses pembelajaran sintaksis belum menggunakan model pembelajaran yang mampu melatih mahasiswa untuk mengorganisasikan sendiri materi yang dipelajari. Pada mata kuliah sintaksis menggunakan model pembelajaran ekspositori, diskusi, dan direct learning. Model pembelajaran tersebut belum menumbuhkan peran aktif mahasiswa sehingga memengaruhi kemampuan dalam memahami sintaksis.

Model pembelajaran merupakan perencanaan yang digunakan sebagai pedoman untuk menerapkan pembelajaran di kelas. Dalam penerapannya, model pembelajaran harus dipahami oleh dosen agar mampu melaksanakan rencana perkuliahan secara efektif dan sesuai dengan kebutuhan mahasiswa karena setiap model pembelajaran memiliki tujuan, prinsip, dan tekanan utama yang berbeda. Model pembelajaran yang digunakan pada penelitian ini adalah model discovery learning agar mahasiswa dapat berinteraksi dalam mengembangkan dan mengeksplorasi diri dengan berbagai kegiatan meliputi stimulus, identifikasi masalah, pengumpulan data, pengolahan data, pembuktian, dan kesimpulan.

Pengembangan modul sintaksis dengan model discovery learning dapat mengakomodasi kebutuhan pembelajaran. Pembelajaran sintaksis dapat dilakukan sesuai dengan tiga ranah pendidikan yang 
meliputi kognitif, psikomotorik, dan afektif dengan menggunakan upaya yang berbeda, yaitu (1) pembelajaran dalam bentuk modul dapat menumbuhkan dasar-dasar pengetahuan tentang kemampuan memahami susunan kata dalam kalimat yang dapat menumbuhkan kemahiran keterampilan berbahasa baik lisan maupun tulisan, (2) modul yang dikembangkan dapat memunculkan interaksi antara mahasiswa dan dosen, (3) modul tersebut dikemas secara sistematis dengan konsep setiap akhir bab berisi latihan, bahan diskusi, dan refleksi, serta disesuaikan dengan kemampuan mahasiswa.

Penelitian ini berbeda dengan penelitian yang dilakukan Adi (2016) dan Devi, et al., (2018). Penelitian Adi (2016) menggunakan Kurikulum 2013 (K-13) mata pelajaran fisika sedangkan penelitian ini menggunakan kurikulum perguruan tinggi mata kuliah sintaksis. Penelitian Devi, et al., (2018) mengembangkan bahan ajar menulis teks prosedur kompleks sedangkan penelitian ini mengembangkan modul sintaksis. Penelitian ini sangat dekat dengan penelitian Asyhar (2014) yaitu fenomena perubahan bahasa yang terjadi pada bahasa Indonesia dan menjawab persoalan yang sering ditanyakan yakni apakah perubahan kata dan makna kata itu terjadi secara keseluruhan atau ada pola di belakangnya.

Penelitian pendahuluan yang dilakukan Asyhar (2014) menjelaskan bahwa perubahan fonologis bahasa Indonesia berupa perubahan lenisi, perubahan penguatan bunyi, penambahan bunyi, penghilangan bunyi, reduksi konsonan rangkap, anaptiksis, disimilasi, fusi, dan haplologi, sedangkan perubahan semantis kosakata bahasa Indonesia dapat diklasifikasikan menjadi tiga jenis, yakni perubahan makna menyempit, meluas, dan bersifat total. Perubahan semantis kosakata bahasa Indonesia cenderung mengarah pada perluasan makna.

Selanjutnya penelitian yang dilakukan oleh Adi (2016) memaparkan bahwa kemampuan berpikir kritis dan kreatif berbasis discovery learning telah diperoleh hasil efektif untuk meningkatkan kemampuan berpikir kreatif berdasarkan $N$ gain score 0,40 (SMAN 2) dan 0,40 (SMAN 6) dan efektif meningkatkan prestasi belajar berdasarkan hasil $N$-gain score 0,40 (SMAN 2) dan 0,60 (SMAN 6). Penelitian Devi, et al., (2018) memaparkan ujicoba kelas XI SMA menunjukkan 86\% sangat valid. Dari hasil analisis data melalui rumus uji t-test menghasilkan Thitung $(13,68)>$ ttabel $(1,703)$, sehingga terdapat perbedaan kognitif antara sebelum dan sesudah siswa menggunakan bahan ajar yang dikembangkan dalam buku dengan pemodelan pembelajaran discovery learning menggunakan media audio visual pada materi teks prosedur kompleks kelas XI. Maka hasil pengembangan yang telah dilakukan mampu meningkatkan hasil belajar siswa.

Merujuk pada pemaparan di atas, penelitian ini bertujuan untuk (1) mendeskripsikan proses pengembangan modul sintaksis dengan model discovery learning, dan; (2) mendeskripsikan kualitas modul sintaksis dengan model discovery learning untuk mahasiswa Pendidikan Bahasa Indonesia di Universitas Billfath.

\section{METODE}

Penelitian ini merupakan penelitian dan pengembangan yang bertujuan untuk menghasilkan suatu produk berupa modul. Subjek penelitian pada penelitian ini adalah mahasiswa Program Studi Pendidikan Bahasa Indonesia Universitas Billfath Lamongan. Model pengembangan yang digunakan adalah model pengembangan ADDIE yang dirancang oleh Reiser dan Mollenda (Branch, 2009,p.2). Model pengembangan ini terdiri atas lima tahap yaitu (1) analysis, (2) design, (3) development, (4) implementation, dan (5) evaluation (Branch, 2009:2).

Pertama, tahap analisis peneliti melakukan analisis kebutuhan, mengidentifikasi masalah/kebutuhan, dan melakukan analisis tugas. Pada tahap ini informasi dikumpulkan dengan melakukan prapenelitian yang bertujuan menelaah Kurikulum Perguruan Tinggi (KPT), menelaah karakteristik mahasiswa, latar 
belakang pengetahuan, dan bahan ajar yang digunakan dosen atau mahasiswa. Kedua, tahap perancangan menjadi acuan menyusun modul sintaksis yang disusun sesuai dengan syarat kevalidan, kepraktisan, dan keefektifan. Tahap ini dirinci menjadi tahap perancangan awal, format bahan, dan validasi. Ketiga, tahap pengembangan bertujuan untuk mengidentifikasi dan mengurangi kesalahan dalam modul serta memperoleh komentar mengenai isi modul. Tahap ini menghasilkan produk melalui (1) penilaian ahli (expert appraisal), (2) uji coba perangkat yang dikembangkan (development testing). Penilaian oleh ahli bertugas memvalidasi perangkat yang menghasilkan kevalidan, kepraktisan, dan keefektifan modul sintaksis dengan model discovery learning. Uji coba perangkat melalui dua tahap yaitu uji coba terbatas dan uji coba luas. Keempat, tahap implementasi melaksanakan program pembelajaran dengan menerapkan modul sintaksis dengan model discovery learning. Kelima, tahap evaluasi melakukan evaluasi program pembelajaran dan evaluasi hasil pembelajaran. Evaluasi dilakukan pada mahasiswa jurusan Pendidikan Bahasa Indonesia Universitas Billfath.

\section{HASIL DAN PEMBAHASAN}

Hasil penelitian menunjukkan bahwa modul sintaksis dengan model discovery learning valid, efektif, dan praktis untuk mahasiswa Pendidikan Bahasa Indonesia. Kevalidan diperoleh dari hasil angket validasi ahli materi. Keefektifan diperoleh dari aktivitas mahasiswa, aktivitas dosen, dan ketuntasan hasil belajar mahasiswa. Kepraktisan diperoleh dari keterlaksanaan SAP, respons mahasiswa, dan respons dosen.

Hasil validasi ahli materi terhadap modul pembelajaran yang dikembangkan sebagai berikut.

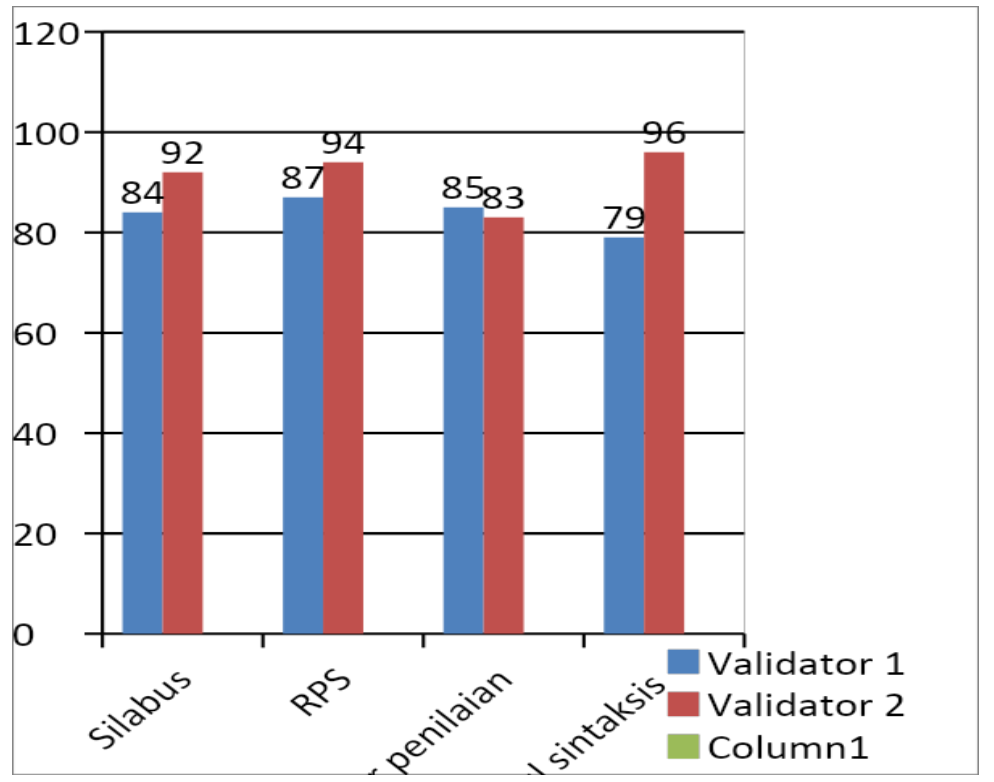

Data kevalidan perangkat pembelajaran modul sintaksis berdasarkan rekapitulasi perhitungan rata-rata penilaian validator ahli 1 dan 2 terhadap seluruh komponen perangkat pembelajaran terangkum dalam tabel berikut.

Tabel 1. Rekapitulasi Hasil Validasi Ahli

\begin{tabular}{clcc}
\hline No & Komponen perangkat pembelajaran & $\begin{array}{c}\text { Penilaian Validator } \\
\text { dalam Persen }\end{array}$ & Kategori \\
\hline 1 & Silabus & 91 & sangat valid \\
2 & Lembar Penilaian & 84 & valid \\
3 & Rencana Pembelajaran Semester (RPS) & 90,3 & sangat valid \\
4 & Modul Sintaksis & 88 & sangat valid \\
\hline
\end{tabular}


Ketercapaian keefektifan modul sintaksis dirangkum pada tabel berikut.

Tabel 2. Rekapitulasi Keefektifan Modul Sintaksis

\begin{tabular}{ccccc}
\hline Kriteria/Hasil & $\begin{array}{c}\text { Aktivitas } \\
\text { Mahasiswa }\end{array}$ & $\begin{array}{c}\text { Aktivitas } \\
\text { Dosen }\end{array}$ & $\begin{array}{c}\text { Ketuntasan } \\
\text { Hasil Belajar }\end{array}$ & Kriteria Kepraktisan \\
\hline Nilai & $80,2 \%$ & $86 \%$ & $97 \%$ & \multirow{2}{*}{ efektif } \\
\hline Kategori & Baik & sangat baik & tuntas & \\
\hline
\end{tabular}

Tingkat ketercapaian keefektifan, berdasarkan pada Tabel 2 diperoleh nilai aktivitas mahasiswa $(80,2 \%)$ dengan kategori baik, aktivitas dosen (86\%) dengan kategori sangat baik, dan ketuntasan hasil belajar mahasiswa (97\%). Hasil ketercapaian keefektifan menunjukkan modul sintaksis dalam kategori efektif.

Data kepraktisan modul sintaksis terangkum dalam tabel rekapitulasi sebagai berikut.

Tabel 3. Rekapitulasi Pengkategorian Kepraktisan Modul Sintaksis

\begin{tabular}{ccccc}
\hline Kriteria/Hasil & SAP & $\begin{array}{c}\text { Respons } \\
\text { Mahasiswa }\end{array}$ & Respons Dosen & Kriteria Kepraktisan \\
\hline Nilai & $90 \%$ & $85 \%$ & $90 \%$ & \multirow{2}{*}{ sangat praktis } \\
\hline Kategori & sangat baik & positif & positif & \\
\hline
\end{tabular}

Berdasarkan hasil rekapitulasi tingkat ketercapaian kepraktisan pada tabel 3 diperoleh nilai keterlaksanaan SAP (90\%) dengan kategori sangat baik, angket respons mahasiswa dengan nilai (83\%) menunjukkan respons positif, dan respons dosen dengan nilai $(90 \%)$ menunjukkan respons positif. Dengan demikian, dapat disimpulkan bahwa modul sintaksis dalam kategori sangat praktis.

Berdasarkan hasil penelitian ditemukan keadaan yang terbentuk menjadi proposisi, yaitu: (a) kevalidan modul sintaksis meningkatkan kemampuan kognitif mahasiswa pada materi sintaksis, (b) keefektifan modul sintaksis sebagai strategi efektif dalam pembelajaran penemuan, (c) kepraktisan modul sintaksis menunjukkan kemudahan bagi dosen dan mahasiswa.

Kevalidan menjadi latar belakang komponen-komponen yang dikembangkan dalam modul sintaksis dengan tidak mengandung kesalahan karena didasarkan pada rasional teoritik yang kokoh. Validasi modul sintaksis bertujuan untuk mengetahui kelayakan modul pembelajaran yang dihasilkan sebelum digunakan dalam pembelajaran. Hasil validasi adalah data untuk mengukur kevalidan modul sintaksis, serta saran atau masukan dari validator. Modul sintaksis dan perangkat pembelajaran yang sudah divalidasi kemudian direvisi berdasarkan saran dan masukan validator.

Penilaian perangkat pembelajaran (silabus, RPS, SAP, lembar penilaian, RPP, dan modul sintaksis) dilakukan oleh dua dosen ahli bahasa dan ahli pembelajaran pada tanggal 1-26 November 2018. Validator memerlukan waktu selama itu karena harus memeriksa dengan teliti seluruh desain perangkat pembelajaran. Validator memberikan saran dan masukan terkait kebahasaan (ejaan dan tata bahasa), pengajaran, model pembelajaran yang selanjutnya dijadikan dasar untuk perbaikan. Meskipun desain perangkat pembelajaran telah disusun dan disunting dengan melibatkan dosen pembimbing, namun masih terdapat kesalahan yang harus diperbaiki dan disempurnakan. Desain awal yang telah dinilai oleh validator ahli menghasilkan draf yang berkualitas dan layak digunakan. Hal ini menunjukkan bahwa draf perangkat pembelajaran mampu menarik dan memberi kemudahan bagi penggunanya (dosen dan mahasiswa) ketika diujicobakan dalam proses perkuliahan. 
Bentuk penyajian modul sintaksis didesain sesuai dengan proses perencanaan pembelajaran agar dapat mencapai sasaran. Sasaran yang dimaksud adalah kompetensikompetensi yang harus dicapai oleh mahasiswa, yakni mampu menggunakan modul sintaksis dan mampu meningkatkan kompetensi mahasiswa sesuai dengan tujuan pembelajaran. Tujuan pembelajaran adalah target kualifikasi kemampuan mahasiswa yang meliputi kognitif (pengetahuan), afektif (sikap), dan psikomotor (keterampilan) yang dicapai pada pokok bahasan tertentu. Pemahaman terhadap tujuan pembelajaran ini penting agar diketahui target yang harus dicapai dalam tujuan pembelajaran.

Kemampuan mahasiswa berusia di atas 18 tahun adalah kelompok adolesens dan dewasa (muda). Kemampuan kognitif mahasiswa menggunakan konsep Piaget (dalam Ibda, 2015,p.27) menyatakan bahwa tahap kognitif dimulai dari proses berpikir konkret sampai dengan berpikir lebih tinggi atau berpikir formal operasional. Pada tahap ini mahasiswa mampu berpikir: (1) hipotesis-abstrak, (2) deduktif-induktif, (3) analisis-sintesis, (4) konvergen-divergen, (5) pemecahan masalah, dan (6) berpikir kreatif.

Kemampuan mahasiswa dalam aspek afektif menggunakan tahapan perkembangan moral Kohlberg (dalam Slavin, 2011) menyatakan bahwa mahasiswa berada pada tahapan pertimbangan katahati (Conscience-principle) yaitu suatu tahapan kesadaran moral yang perbuatannya didasarkan atas keputusan kata-hati. Perbuatan baik dilakukan tanpa melihat atribut-atribut tertentu.

Kemampuan mahasiswa dalam aspek psikomotor menggunakan tahapan perkembangan Maslow (1993, p.43-45) menyatakan bahwa mahasiswa berada pada tahap aktualisasi diri yaitu mengaktualkan semua potensi yang dimilikinya. Kemampuan sosialnya telah mampu mandiri (Independence- autonomy) yaitu mampu melakukan kerjasama secara luas, mampu memimpin kelompok besar, serta telah memiliki kemampuan bahasa kompleks. Mahasiswa mampu mengembangkan semua potensi, kecakapan dan karakteristiknya secara optimal jika didukung pendekatan, model, dan metode pembelajaran yang sesuai dengan tahap perkembangan dan kemampuan mahasiswa tersebut.

Pemahaman tentang kemampuan kognitif mahasiswa dalam materi sintaksis ini penting untuk direncanakan agar diketahui hal-hal yang perlu dipertajam dalam pembelajaran. Pemahaman tentang karakteristik mahasiswa juga penting untuk merencanakan model pembelajaran yang dibutuhkan dan menanamkan karakter baik. $\mathrm{Hal}$ ini sesuai dengan karakteristik proses pembelajaran berdasarkan Permenristekdikti No. 442015 tentang SN Dikti Pasal 11 bahwa untuk meraih capaian pembelajaran lulusan pembelajaran harus interaktif, holistik, integratif, saintifik, kontekstual, tematik, efektif, dan berpusat pada mahasiswa.

Secara akademik kemampuan mahasiswa berada pada level menengah karena memiliki nilai rerata 3,14 dan 3,25 (Lampiran 1D.5). Berdasarkan hasil identifikasi kemampuan awal mahasiswa dalam perkuliahan sintaksis, mahasiswa masih perlu mempertajam pemahaman tentang hakikat sintaksis, teori sintaksis, materi frasa, materi klausa, dan materi kalimat.

Hasil diskusi (wawancara) dengan dosen bahasa Indonesia di Universitas Billfath, karakter yang perlu ditanamkan kepada mahasiswa adalah karakter disiplin, komunikatif, peduli lingkungan, kerjasama, toleransi, kreatif, percaya diri, dan tanggung jawab. Karakter tersebut dapat diimplementasikan melalui kegiatan skenario pembelajaran, materi pembelajaran, model pembelajaran, dan penilaian pembelajaran.

Bertitik tolak dari hasil identifikasi kemampuan kognitif mahasiswa dan diskusi dengan dosen Bahasa Indonesia, kesulitan mahasiswa dalam pembelajaran sintaksis adalah memecahkan masalah dalam analisis kalimat. Analisis kalimat mempunyai tujuan membantu mahasiswa membangun 
gambaran tentang materi sintaksis yang telah diikuti sebelumnya. Berdasarkan tujuan tersebut, Silberman (2006, p.134) menyebutkan bahwa ada kalanya sejumlah konsep masih belum bisa dipahami, betapapun sudah dijelaskan secara verbal dan visual. Salah satu cara untuk membantu mahasiswa membangun gambaran tentang materi yang dibelajarkan adalah mempraktikkannya.

Analisis kalimat berkenaan dengan kegiatan menganalisis berdasarkan struktur kalimat. Mahasiswa harus menentukan jenis kalimat dan mengidentifikasi unsur pembentuk kalimat. Mahasiswa juga harus memiliki kemampuan merangkaikan kalimat. Hasil diskusi tersebut digunakan untuk menyunting hasil analisis kalimat yang sudah dikerjakan mahasiswa agar proses pembelajaran berjalan dengan efektif.

Keefektifan modul sintaksis diukur berdasarkan hasil ketuntasan belajar mahasiswa. Indikator pencapaian kompetensi tes hasil belajar mahasiswa mengacu pada kompetensi dasar (KD) mata kuliah sintaksis bahasa Indonesia. Keefektifan dapat diartikan tingkat keberhasilan yang dapat dicapai dari suatu cara atau usaha tertentu sesuai dengan tujuan yang akan dicapai. Faktor-faktor yang memengaruhi keefektifan dalam pembelajaran yaitu kemampuan dosen dalam menggunakan metode pembelajaran. Di mana metode pembelajaran dipengaruhi oleh faktor tujuan, siswa, situasi, fasilitas, dan pengajar itu sendiri.

Efektif tidaknya kegiatan pembelajaran diketahui dengan memberikan tes sebagai evaluasi berbagai aspek proses pembelajaran. Menurut Soemosasmito dalam Trianto (2010,p.20) menyatakan bahwa suatu pembelajaran dikatakan efektif apabila memenuhi beberapa persyaratan utama keefektifan pembelajaran, yaitu (a) presentasi waktu belajar mahasiswa yang tinggi terhadap KBM; (b) rata-rata perilaku mahasiswa dalam melaksanakan tugas sintaksis; (c) ketepatan antara kandungan materi sintaksis dan kemampuan mahasiswa; (d) mengembangkan suasana belajar yang akrab dan positif.

Keefektifan penggunaan modul sintaksis dilihat dari kemandirian belajar mahasiswa dan hasil belajar sintaksis. Jika tingkat kemandirian belajar dan hasil belajar sintaksis menggunakan modul sintaksis lebih tinggi dari yang tidak menggunakan modul sintaksis, maka modul sintaksis dikatakan efektif.

Kegiatan pembelajaran sintaksis secara umum dilakukan dengan diskusi kelompok dan presentasi. Masukan dari kelompok lain dalam kegiatan presentasi dan penguatan dari dosen dapat dipakai sebagai bahan penyempurnaan hasil mengidentifikasi masalah. Berdasarkan uraian tersebut, kegiatan mengidentifikasi masalah akan menghasilkan penemuan konsep. Hal ini sesuai dengan teori belajar Bruner (dalam Carin \& Sund, 1975), yaitu (1) individu hanya belajar dan mengembangkan pikirannya saat menggunakan pikirannya, (2) dengan melakukan proses kognitif dalam proses penemuan, mahasiswa mampu memperoleh sensasi dan kepuasan intelektual yang menjadi penghargaan intrinsik, (3) satu-satunya cara agar seseorang dapat mempelajari teknik dalam melakukan penemuan adalah adanya kesempatan untuk melakukan penemuan, dan (4) dengan melakukan penemuan maka memperkuat retensi ingatan. Empat hal di atas adalah bersesuaian dengan proses pembelajaran menggunakan modul sintaksis.

Evaluasi pembelajaran dilakukan untuk mengetahui keberhasilan proses pembelajaran dan kualitas produk pengembangan. Kegiatan yang dilakukan mahasiswa adalah mengisi instrumen yang dapat digunakan untuk menilai hasil kerja mahasiswa pada materi sintaksis. Kegiatan ini dilakukan untuk mengetahui hasil pembelajaran yang dilakukan mahasiswa sekaligus dapat dipakai sebagai umpan balik bagi dosen untuk memperbaiki kekurangan selama proses pembelajaran. Uraian tersebut senada dengan pernyataan Iskandarwassid dan Sunendar (2008, p.210) bahwa evaluasi dapat digunakan untuk 
menentukan hasil yang dicapai oleh mahasiswa. Evaluasi dapat digunakan pula oleh dosen untuk mengetahui dan memperbaiki masalah pembelajaran.

Lebih lanjut, Djiwandono (2008,p.1) mengemukakan bahwa evaluasi pembelajaran bahasa merupakan upaya untuk memastikan ketercapaian tujuantujuan pembelajaran yang telah dirumuskan. Dengan evaluasi, mahasiswa dapat mengetahui kompetensi yang dicapainya serta dapat memberikan motivasi agar dapat berprestasi ke tingkat yang lebih baik. Bagi dosen, evaluasi digunakan untuk mengetahui kompetensi yang diraih oleh mahasiswa dan digunakan untuk mengambil keputusan secara tepat dalam menentukan langkah-langkah selanjutnya.

Karakteristik evaluasi dalam proses pembelajaran menggunakan modul sintaksis adalah evaluasi dengan instrumen untuk dua macam. Pertama, evaluasi digunakan untuk menemukan konsep terhadap materi yang dipelajari. Proses penemuan konsep, mahasiswa dapat belajar secara individu dan berkelompok, mempresentasikan hasil kerja, dan merevisi hasil kerja yang belum sempurna. Komentar dan masukan antarmahasiswa serta penguatan dari dosen bermanfaat dalam penemuan konsep dalam materi sintaksis. Hal ini sejalan dengan pendapat Alwasilah (2010, p.80) menyatakan bahwa (1) komentar dan masukan dari sesama mahasiswa dan dosen bermanfaat untuk perbaikan pembelajaran; (2) diskusi antara mahasiswa dan dosen dapat menunjang pemahaman mahasiswa terhadap materi yang dipelajari.

Kedua, evaluasi dapat dimanfaatkan untuk membangun keterampilan sekaligus mengukur hasil belajar mahasiswa dalam proses pembelajaran. Proses penemuan konsep dilakukan dengan kerja sama dalam kelompok, bertanggung jawab dalam menyelesaikan tugas belajar, dan merevisi hasil belajar yang belum sempurna.

Penerapan modul sintaksis dilakukan untuk mengetahui respons dosen dan respons mahasiswa dalam memahami materi sintaksis. Reiser dan Mollenda
(Branch, 2009,p.133) menyatakan bahwa tahap penerapan mempersiapkan lingkungan belajar dengan melibatkan mahasiswa yang yang terdiri atas dua hal yaitu (1) mempersiapkan dosen, dan (2) mempersiapkan mahasiswa. Pada tahap penerapan, mahasiswa melakukan proses pembelajaran menggunakan modul sintaksis. Kegiatan ini bertujuan agar mahasiswa memperoleh informasi tentang materi yang dipelajari. Proses pembelajaran menggunakan modul sintaksis mencakup membaca, mengidentifikasi masalah, mengumpulkan dan mengolah informasi serta menemukan konsep.

Perangkat pembelajaran yang berkualitas dalam penelitian pengembangan memerlukan penyuntingan berlapis dari para ahli bahasa dan ahli pembelajaran. Modul sintaksis memiliki rata-rata nilai sebesar (88\%) dengan kategori sangat baik mengacu pada Tabel 3.10 kategori penilaian (Purwanto, 2010, p.103), halaman 66. Instrumen modul sintaksis memiliki kategori penilaian layak dengan rata-rata nilai skor validator 4,0 sehingga instrumen modul sintaksis dapat digunakan dalam pembelajaran. Hasil perhitungan komponen kelayakan modul sintaksis tersaji pada Tabel 4.4.

Aktivitas mahasiswa dalam menerima pelajaran baik, hal ini dilihat dari nilai ratarata $80,2 \%$ dengan kategori baik. Hasil pengamatan aktivitas mahasiswa tersaji pada Tabel 4.6 dengan simpulan mahasiswa aktif dalam proses pembelajaran. Hal ini berbeda dengan hasil penelitian Ula (2018) yang menghasilkan skor rata-rata aktivitas mahasiswa 93,6\% dengan predikat sangat baik. Nilai ini menggambarkan di atas nilai ambang batas kelulusan. Artinya, aktivitas dalam respons menerima materi, respons mahasiswa saat pemahaman materi, respons mahasiswa saat mengerjakan soal-soal dari modul, waktu yang diperlukan mahasiswa untuk menerima materi, dan latihan-latihan soal dari modul sangat baik.

Mahasiswa mampu merespons secara positif modul sintaksis. Dari angket respons mahasiswa, mahasiswa merespons tertinggi pada aspek dalam angket "Apakah Anda 
berminat untuk mengikuti pembelajaran seperti ini (pembelajaran yang berorientasi pada penemuan konsep) pada kegiatan belajar mengajar berikutnya atau pada kompetensi yang lain?" (92\%) mahasiswa merasa berminat, (84\%) mahasiswa merasa jelas ketika dosen memberi bimbingan melaksanakan praktik sehingga $(83 \%)$ mahasiswa merasa mudah dalam mencapai tujuan, (82\%) mahasiswa merasa senang dengan perkuliahan sintaksis menggunakan perangkat baru, dan (83\%) merasakan mendapatkan kemudahan menggunakan modul sintaksis.

Berdasarkan respons mahasiswa menunjukkan bahwa mahasiswa merasa tertarik dan mendapat kemudahan dengan menggunakan modul sintaksis. Keberhasilan mahasiswa mencapai kompetensi pembelajaran sintaksis, salah satunya juga karena peran motivasi dari dosen. Hal ini sesuai dengan pendapat Biggs dan Telfer (1987) dalam Ilyas (2013) yang menyatakan bahwa di antara motivasi belajar ada yang diperkuat dengan kegiatan pembelajaran yang dapat memengaruhi proses belajar dan kegiatan pembelajaran tersebut dapat ditentukan oleh dosen.

Respons dosen terhadap modul produk sangat positif dengan persentase sebesar (90\%). Kegiatan respons dosen terhadap modul produk adalah untuk menilai kelayakan modul produk di kelas. Penerapan buku bagi dosen merupakan bahan renungan kelemahan dan kekuatan modul produk. Tentunya dosen akan merespons dari segi penyajian, materi/isi, dan kebahasaan.

Sementara itu, dosen menilai modul pembelajaran yang dikembangkan berdasarkan angket respons skor tertinggi sebesar $100 \%$ pada pernyataan "memberi kemudahan dalam mengorganisir kerja mahasiswa". Selanjutnya, dengan skor $88 \%$ dosen merasa diberi kemudahan dalam menyampaikan materi perkuliahan, mengelola waktu, membuat pembelajaran berpusat pada penemuan konsep mahasiswa, pembelajaran menjadi lebih menarik, dan melatih mahasiswa bekerja sama untuk menemukan konsep dari materi yang dipelajari. Hal itu menjelaskan bahwa modul sintaksis memudahkan dosen dalam proses perkuliahan.

Dengan demikian, dapat disimpulkan bahwa perangkat pembelajaran ini dinilai berdasarkan hasil keterlaksanaan SAP $(90 \%)$ berkategori baik, respon positif mahasiswa (85\%), dan respon positif dosen $(90 \%)$ dengan kategori sangat praktis dan layak digunakan namun tetap perlu disempurnakan.

Berdasarkan data hasil penilaian modul pembelajaran ini, menurut kriteria Nieveen, et al., (1999,p.127) menyatakan bahwa perangkat pembelajaran valid, praktis, dan efektif. Dengan demikian, dapat disimpulkan bahwa modul sintaksis dinyatakan berkualitas dan layak digunakan. Proses pengembangan modul sintaksis disusun sampai dinyatakan berkualitas dan layak digunakan melalui tahap analisis, perancangan, pengembangan, penerapan, dan evaluasi.

\section{SIMPULAN}

Produk pengembangan modul sintaksis untuk Mahasiswa Pendidikan Bahasa Indonesia di Universitas Billfath berkualitas baik. Hal tersebut terlihat pada hasil validasi ahli sehingga layak digunakan dalam pembelajaran. Modul sintaksis diukur kualitasnya berdasarkan data kevalidan, keefektifan, dan kepraktisan. Data kevalidan modul sintaksis berdasarkan penilaian validator 1 dan 2 diperoleh hasil persentase $(88 \%)$ dengan kategori sangat valid sehingga layak digunakan dalam pembelajaran sintaksis. Data keefektifan modul sintaksis berdasarkan hasil pengamatan aktivitas mahasiswa (80,2\%), hasil pengamatan aktivitas dosen (86\%), dan ketuntasan belajar (97\%). Ketiga hasil persentase menunjukkan keefektifan modul termasuk dalam kategori efektif sehingga mahasiswa mampu belajar secara aktif dan tuntas dalam penilaian. Data kepraktisan modul sintaksis berdasarkan keterlaksanaan RPS (90\%), respons dosen (90\%), dan respons mahasiswa (85\%). Ketiga hasil persentase menunjukkan kepraktisan modul sintaksis termasuk dalam kategori 
sangat praktis sehingga memberi pengaruh positif sangat kuat.

\section{DAFTAR RUJUKAN}

Adi, D. W. (2016). Pengembangan Modul Fisika Berbasis Discovery Learning dengan Pendekatan Problem Based Learninguntuk Meningkatkan Kemampuan Berpikir Kritis dan Kreatif Siswa Kelas XI SMA/MA di Surakarta. Doctoral dissertation, UNS (Sebelas Maret University).

Asyhar, C.(2014). Perkembangan Fonologis dan Semantis Lema-lema dalam Kamus Bahasa Indonesia. Thesis. Surabaya: Unesa.

Branch, B.M. (2009). Instructional Design: The Addie Approach. London: Springer.

Carin, A.A., \& Sund, R.B. (1975). Teaching Science Through Discovery, $3^{\text {rd }}$ Ed. Columbus: Charles E. Merrill Publishing Company.

Devi, P. C., Hudiyono, Y., \& Mulawarman, W. G. (2018). Pengembangan Bahan Ajar Menulis Teks Prosedur Kompleks dengan Model Pembelajaran Discovery Learning Menggunakan Media Audio Visual (Video) di Kelas XI SMA Negeri 1 Samarinda. Diglosia: Jurnal Kajian Bahasa, Sastra, dan Pengajarannya, 1(2), 101-114.

Djiwandono, S. (2008). Tes Bahasa Pegangan Bagi Pengajar Bahasa. Jakarta: Indeks.

Ibda, F. (2015). Perkembangan Kognitif: Teori Jean Piaget. Jurnal Intelektualita, 3(1), 27-36.
Ilyas, M. (2013). Kompetensi Pedagogik Guru Matematika SMK Negeri SeKota Palopo Berdasarkan Pengalaman Mengajar. Jurnal Dinamike, 4(2), 47-58.

Iskandarwassid \& Sunendar, D. (2008). Strategi Pembelajaran Bahasa. Bandung: Rosdakarya.

Maslow, A. (1993). Motivasi dan Kepribadian, alih bahasa: Nurul Iman. Bandung: Rosda Karya.

Nieveen, N., Plomp, T., van den Akker, J., Branch, R.M., \& Gustafson, K. (1999). Design Approaches and Tools in Education and Training. Netherlands: Springer-Science-Business Media.

Permenrsitekdikti No. 44 Tahun 2015 tentang Standar Nasional Pendidikan Tinggi (SN-DIKTI).

Purwanto, N. (2010). Evaluasi Hasil Belajar. Yogyakarta: Pustaka Pelajar.

Prastowo,A. (2013). Pengembangan Bahan Ajar Tematik. Yogyakarta: Diva Press.

Slavin, R.E.(2011). Educational Psychology Theory and Practice. United States of America: Johns Hopkins University

Trianto. (2010). Mengembangkan Model Pembelajaran Tematik. Jakarta: PT. Prestasi Pustaka.

Ula, H. R. (2018). Pengembangan Modul Tata Bahasa Indonesia Berbasis ELearning untuk Mahasiswa BIPA Tingkat Pemula. E-Journal Bapala, 1(1), 1-10.

Undang-Undang Nomor 14 Tahun 2005 tentang Guru dan Dosen. 